DOI https://doi.org/10.30525/978-9934-588-80-8-1.52

\title{
ПРИНЦИП ЦІННІСНОЇ НЕЙТРАЛЬНОСТІ УНІВЕРСИТЕТУ
}

\author{
Зайченко Н. I. \\ доктор педагогічних наук, \\ професор кафедри загальної та прикладної психології \\ ПВНЗ «Інститут екології економіки і права» \\ м. Київ, Украӥна
}

У сучасних нормативно-правових документах про освіту визначається принцип нейтральності університету, зокрема у Законі України «Про освіту» (2017р.) проголошується, що засадами державної політики у сфері освіти 3-поміж інших є невтручання політичних партій в освітній процес; невтручання релігійних організацій в освітній процес; різнобічність та збалансованість інформації щодо політичних, світоглядних та релігійних питань (ст. 6) [1]. У Законі України «Про вищу освіту» (2014р.) зазначено про те, що державна політика у сфері вищої освіти грунтується на принципі незалежності здобуття вищої освіти від політичних партій, громадських і релігійних організацій (крім закладів вищої духовної освіти) (ст. 3) [2].

Принцип ціннісної нейтральності університетів захищали чимало педагогів, філософів, учених. У промові на честь відкриття Валенсійського народного університету 8 лютого 1903 року, викладеній у статті «Нейтральність університету» (1903р.), іспанський педагог, викладач Мадридського університету Гумерсіндо де Аскарате зауважував, що університет не може бути призначений для обслуговування інтересів політичних партій чи релігійних сект, він не може бути ні ліберальним, ні консервативним, ні індивідуалістичним, ні соціалістичним, ні католицьким, ні вільнодумним, оскільки він відкриває лише єдиний шлях - до істини [3, с. 329-330].

На погляд Гумерсіндо де Аскарате, принцип нейтральності університету - то $є$ «поєднання трьох речей: свободи, толерантності, неупередженості» [3, с. 323]. Свобода як умова нейтральності означає, що людині не можуть бути нав'язані ніякі учення, що вона має право за власною волею слідувати тим чи іншим доктринам. Свобода не може ототожнюватися зі свавіллям, із можливістю людини робити усе, що заманеться (це ознака поганого виховання); свобода - то є свідоме керування людиною своїми діями, власними життям та долею. Толерантність - друга умова нейтральності. Вона не сумісна із 
байдужістю, вона грунтується на визнанні того, що у вченні будь-якої партії, будь-якої школи, будь-якої секти наявний певний елемент істини, що саме це вчення не збудоване виключно помилковим шляхом. Нарешті, неупередженість - це наслідок двох попередніх факторів - свободи і толерантності. Неупередженість означає, що «у науки $є$ власна мета, це - пізнання істини, без перетворення їі [науки] на інструмент чогось іншого, що не слугує істині» [3, с. 329].

Відомий німецький філософ, соціолог Макс Вебер у статті «Наука як покликання і професія» (1918р.) стверджував, що «політиці не місце в аудиторії» [4, с. 721]. Ні студент, ні викладач не мають в університетській аудиторії «займатися політикою». На переконання М. Вебера, «там, де людина науки приходить зі своїм власним ціннісним судженням, уже немає місця повному розумінню фактів» [4, c. 722].

Розповсюдженою мудрістю $є$ те, що «істинне може не бути прекрасним і що дещо істинне лише остільки, оскільки воно не прекрасно, не свято і не добро». Дуже загрозливою є ситуація, коли університетський викладач почне виступати в аудиторії у якості вождя, пророка чи-то демагога. Наука нині слугує справі самоусвідомлення та пізнання фактичних зв'язків, вона - не милостивий дар провидців i пророків, не складова частина розмислювання мудреців та філософів про смисл світу [4, с. 731].

Йдеться насамперед про те, що викладач не повинен висловлювати свої політичні переконання, навчаючи студентів. Здобувачі вищої освіти можуть і мають право притримуватися власних політичних поглядів. Для висловлення політичних поглядів та міркувань існує публічний простір.

Визначний іспанський педагог Ф. Хінер де лос Pioc у праці «Іспанський університет» (Мадрид, 1916 р.) наголошував, що університет - це автономна суспільна корпорація, яка є незалежною від церкви i держави, хоча й перебуває в зовнішніх різноманітних відносинах і з першою, і з другою. Провідними функціями університету $€$ такі: «a) культивування науки за допомогою організації досліджень i навчання; б) загальне виховання студентів i захист їхнього інтелектуального, матеріального i духовного життя, як усередині університету, так i поза ним, шляхом підтримки для розвитку особистості; в) поширення культури серед усіх суспільних класів із практикою різних форм університетського розширення; г) вище управління національним вихованням (не авторитарний, а моральний i ліберальний вплив); д) педагогічна підготовка, пряма i непряма, викладацького загалу за усіма напрямами» [5, с. 143-144]. 
Університет призначений творити думку, свідомість, світогляд, він - живий учасник громадянського життя, взірець і транслятор культурних цінностей, на яких зводитиметься будівля прийдешнього суспільства. Університетська освіта дозволяє людині осмислювати ті суспільно-культурні процеси, які властиві iï часу, усвідомлювати історичний хід речей, бачити власне призначення у соціумі. Університет як universum-знання озброює людину інструментами підкорення та змінення світу. Університет не призначений для обслуговування корисливих інтересів певних політичних угруповань, не призначений для захисту догм яких би то не було релігій. У нього інша місія. Коли університет почне притримуватися тієї чи іншої політичної ідеології, він утратить саму свою сутність - володарювання над об'єктивним знанням. Це загрожуватиме виродженням національного інтелекту. Не припустимо, виплекану віками, інтелігентність університету розмінювати на сьогохвилинне оманливе політичне уподобання, адже міць університету вимірюється силою його внутрішнього духу, здатного протистояти усіляким зовнішнім впливам, тим паче привабливо декорованим.

У книзі «Ідея університету» (Берлін, 1946 р.) німецький філософ Карл Ясперс писав: «Тільки-но виникає університетська освіта, вона одразу стає науковою освітою. Вона визначається завдяки науковому способу дій у цілому і через зміст наук, які знаходяться в освіті на передньому плані. Наукова позиція - більше ніж наукові знання та професійні навички. Вона є здібністю відсторонити на якийсь момент власні цінності на користь об'єктивного пізнання, бути спроможним відмовитися від власної точки зору, власних актуальних бажань на користь неупередженого аналізу фактів. Тим самим не тільки досягається об'єктивно вільне пізнання, але й змінюється досвід власного відданого певним поглядам існування. Скасовуються фанатизм і сліпота» [6, с. 60].

Таким чином, саме принцип ціннісної нейтральності має лежати в основі функціонування університету, оскільки його основною метою $\epsilon$ творення нового наукового знання та трансмісія останнього із теперішнього у прийдешнє.

\section{Література:}

1. Закон України. Про освіту. URL: https://zakon.rada.gov.ua/ laws/show/2145-19\#Text.

2. Закон України. Про вищу освіту. URL: https://zakon.rada.gov.ua/ laws/show/1556-18\#Text. 
3. Azcarate G. Neutralidad de la Universidad. La Escuela Moderna. 1903, mayo. № 146, año XIII. P. 321-337.

4. Вебер М. Избранные произведения: пер. с нем. / сост., общ. ред. и послесл. Ю. Н. Давыдова. М. : Прогресс, 1990. 808 с.

5. Giner F. La Universidad Española. Madrid: Imp. Clasica Espanola, Cardinal Cisneros, 1916. 303 p.

6. Ясперс К. Идея университета / пер. с нем. Т. В. Тягуновой; под общ. ред. М. А. Гусаковского. Минск: БГУ, 2006. 159 с.

DOI https://doi.org/10.30525/978-9934-588-80-8-1.53

\title{
СОЦІАЛЬНА ВІДПОВІДАЛЬНІСТЬ ЯК НЕВІД'ЄМНА СКЛАДОВА ФОРМУВАННЯ ОСОБИСТОСТІ СУЧАСНОГО ФАХІВЦЯ СФЕРИ ПОСЛУГ
}

\author{
Іванова О. А. \\ заступник директора з навчальної роботи \\ Комериійний технікум \\ Дніпровського державного технічного університету \\ м. Кам'янське, Дніпропетровська область, Україна
}

Вдосконалення професійної підготовки майбутніх фахівців сфери послуг з метою приведення іï у відповідність до сучасних вимог $\epsilon$ сьогодні актуальним питанням сучасної професійної освіти. Нові вимоги до професійної підготовки здобувача освіти у закладах фахової передвищої освіти (до рівня освіти, професіоналізму, ціннісних орієнтацій) зміщують акценти на формування професійно важливих якостей, серед яких особливе значення має сформована активна професійна позиція. Формування активної професійної позиції майбутнього фахівця, на нашу думку, сприятиме становленню особистості здобувача освіти як професіонала, значно полегшить його реалізацію у професійному середовищі.

Одним із шляхів вирішення зазначених завдань $\epsilon$ визначення структурних компонентів активної професійної позиції фахівця сфери послуг.

На нашу думку, одним із елементів активної професійної позиції фахівця сфери послуг, є соціальний компонент. Зважаючи на те, що фахівці сфери послуг за змістом своїх професій пов'язані із забезпеченням комфорту населення, саме соціальна відповідальність має стати основою активної професійної поведінки. 